\section{Efficacy and Economic Value of Weed Control for Drip and Sprinkler Irrigated Celery}

\author{
Edmund J. Ogbuchiekwe and Milton E. McGiffen, Jr. ${ }^{1}$ \\ Department of Botany and Plant Sciences, University of California, Riverside, \\ CA 92521-0124
}

Additional index words. hand-weeding, cost-benefit analysis, Apium graveolens, Brassica kaber, Chenopodium album, Lolium perenne, Sisymbrium irio, herbicide

\begin{abstract}
Economic analyses compared the returns of weed control methods for drip and sprinkler irrigated celery (Apium graveolens L. 'Sonora'). The nine treatments included an untreated control, cultivation as needed for weed control, a pre-emergent herbicide (trifluralin), and six post-emergent herbicides. The effect of each treatment on weed control, yield, crop value, cost of control, costs for additional hand-weeding, net return, and dollar investment (marginal rate of return) was determined. The treatments that reduced weed populations under drip and sprinkler irrigation also increased yield, net returns, and rate of returns. Effective weed control reduced the additional costs of handhoeing the weeds not killed by herbicides, resulting in greater net return. The net returns of weed control were even greater when celery was drip irrigated than when sprinklers were used. In 1998, the sprinkler irrigated field returned $\$ 1148$ to $\$ 3921 /$ ha, compared with $\mathbf{- \$ 5 9 8 4}$ for the untreated control. Net returns for drip irrigation were much higher, ranging from $\$ 3904$ to $\$ 9187 /$ ha compared with $-\$ 8320$ for the untreated control. Net returns were also higher in 1999 , ranging from $\$ 2466$ to $\$ 5389$ when weeds were controlled compared with a net loss of $\$ \mathbf{5 7 1 0}$ for the untreated control in the sprinkler irrigated field. The returns on the drip-irrigated field were much higher, from $\$ 6481$ to $\$ 8920$ when weeds were controlled, compared with $\mathbf{- \$ 8 0 4 6}$ for the untreated control. The associated returns for every dollar invested (marginal rate of return) in the nondominated treatment (more return and lower cost) ranged from 52\% to $156 \%$ for sprinkler irrigation, and $59 \%$ to $144 \%$ for drip irrigation in 1998. In 1999, the rate of return for each dollar invested ranged from $104 \%$ to $324 \%$ for sprinkler and $2.4 \%$ to $321 \%$ for drip irrigated fields.
\end{abstract}

Celery is a cool-season, high-value vegetable that requires intensive management to produce a crop of acceptable quality. The 849,297 metric tons of celery produced in the United States is worth $\$ 219,625,000$ (USDA, 1999). California produces $75 \%$ of American's celery, followed by Florida and Texas (California Dept. of Food and Agriculture, 1996). Most of California's celery is grown near the central and southern coast, with smaller acreage in the desert valleys of Coachella and Imperial (Reitz et al., 1999).

Virtually all California celery plantings are started from transplants. Coastal celery is transplanted from early August to April for harvest from November to mid-July. Sprinkler irrigation is generally used to establish the transplants, followed by sprinkler, furrow, or drip irrigation until harvest. With water costs exceeding \$200/ha-meter in coastal California, many growers are shifting to drip irrigation to reduce water costs. From 1.88 to 2.25 /hameter (3083 to $3700 \mathrm{~m}^{2}$ ) of water is used to grow celery using furrow or sprinkler irrigation, compared to 1.28 to 1.51 /ha-meter (2096 to $2466 \mathrm{~m}^{2}$ ) with drip irrigation (Koike et al.,

Received for publication 2 Oct. 2000. Accepted for publication 2 May 2001.

${ }^{1}$ To whom reprint requests should be addressed. E-mail address milt@citrus.ucr.edu
1996). There is a $67 \%$ water savings when drip irrigation is used in place of sprinkler irrigation. At least $30 \%$ of celery acreage is now drip irrigated in California. Drip irrigation is the most effective system for estimating the amount of water the crop requires for growth and monitoring the depletion of available water in the crop root zone (Hartz, 2000). Drip irrigation produces higher marketable yield and reduces costs by reducing foliar pathogen and weed populations (Erik, 1995). Sprinkler irrigation favors bacterial infiltration and disease development (Little et al., 1997). However, installation and management costs of drip irrigation could go as high as \$227/ha (Mayberry et al., 1995).

Celery is a very high value crop, worth $\$ 179,433,000 /$ ha in 1996 (California Dept. of Food and Agriculture, 1996). Production requires extensive inputs of labor and expendable costs. Environmental stress and pests can readily reduce crop quality and yield, leading to large losses in crop value (Little, 1997). Weeds can severely reduce yield by direct competition, making it uneconomical to harvest the crop. Integrated weed management practices in celery include early weed removal, pre-plant irrigation, disking to kill weed seedlings, and timing the planting date to reduce cultural controls are seldom completely effecweed impact (Koike et al., 1996). However, tive. Because celery transplants compete poorly with weeds, herbicides are important inputs. Herbicides allow transplants to establish a root system and form a canopy that can shade out weeds. Herbicides, assuming they are safe to the crop and effective on common weeds, are also important tools for producing high quality celery. The most commonly used celery herbicides are prometryn, linuron, glyphosate, sethoxydim and trifluralin. Herbicides and date of registration for celery use were as follows: prometryn (1982), linuron (1986), glyphosate (1992), sethoxydim(1983), and trifluralin (1998) (U.S. Environmental Protection Agency, 2000).

While weeds are known to reduce economic value, there are no published cost studies of the value of various weed control methods in celery. This study seeks to compare the efficacy and economic returns of hand-weeding and herbicides for both sprinkler and dripirrigated celery.

\section{Materials and Methods}

Experimental planting of fresh-market celery (cv. Sonora) and different weed species were established at the Univ. of California's South Coast Research and Extension Center in Irvine during the winters of 1997 and 1998. Celery was transplanted by hand on 12 Dec. 1997 and 16 Dec. 1998 in double rows spaced $22.5 \mathrm{~cm}$ apart. A uniform weed infestation was created with species typical of celery fields. Seed of Italian ryegrass (Lolium perenne L.) and the broadleaf weeds wild mustard [Brassica kaber (D.C.) wheeler], common lambsquarters (Chenopodium album L.), and London rocket (Sisymbrium irio L.) were broadcast across the bed top at the population density of 20 weeds $/ \mathrm{m}^{2}$. Celery plants and weeds were grown following standard commercial practices.

The experimental design was a randomized complete block with three replications in 1997 and four replications in 1998. Individual plots were $3.3 \mathrm{~m}$ wide $\times 5 \mathrm{~m}$ long and consisted of three beds. The experimental plot was divided into two adjacent fields, one irrigated with drip and the other irrigated with sprinkler. Weed control treatments were the same in both fields: hand-weeding, trifluralin-applied just before transplanting (pre-emergence), prometryn or linuron-applied after transplanting (post-emergence), and glyphosate applied post-emergence just after weeds emerged but before transplanting (Table 1). Post-emergent applications were made on 22 Dec. 1997 and 22 Dec. 1998. All herbicides were applied with a backpack $\mathrm{CO}_{2}$ sprayer with 8003 nozzles delivering $185 \mathrm{~L}$ of spray solution per hectare.

Both fields were visually rated for weed control and crop injury 2 to 8 weeks after treatment. A visual scale of 0 to 10 was used, where $0=$ no weed control and $10=$ complete weed control (Table 1). For crop injury, $0=$ no damage to the crop and $10=$ death of the celery plant.

Herbicides may kill weeds, partially reduce weed growth, or have no effect on weeds that emerge after post-emergent treatments. 
Partial herbicidal control has a practical economic benefit (return) of reduced labor costs for hand-hoeing. Nevertheless, if no hoeing is done to remove weeds, even herbicide-stunted weeds may be sufficient to reduce crop yields.

Because hand-hoeing is commonly used in combination with herbicide treatments for weed control in celery production, labor costs for hoeing were used as an additional measure of the value of weed treatments. After the visual rating, hand-hoeing was used to remove any weeds remaining in the herbicide-treated plots. Hand-hoeing time and labor were carefully monitored and recorded (Table 2). Typical labor costs were used to calculate the economic value of each weed control method in terms of hand-hoeing costs and net return from harvested yield (Mayberry et al., 1995).

Celery was harvested at maturity on 8 May 1998 and 4 May 1999 and sorted into marketable stalks. Marketable yield was used to calculate the net return of all treatments. Thus, net return represented total gross revenues less costs (growing, hand weeding, herbicide/ application, and harvest) and should not be called net profit since net return estimates includes production costs that were common to all treatments. Yield data were subjected to analysis of variance (ANOVA) (treatments and years), and the treatment means were separated by LSD at $P \leq 0.05$ (Table 2 ).

An economic comparison of weed control treatments vs. the effect on yield and marginal rate of return was calculated using partial budget (Fig. 1), dominance (Table 4), and marginal analysis (Table 5) methods (Centro Internacional de Mejoramiento de Maiz y Trigo, Manual, 1988). The value of celery yield was calculated based on the 1 June 1998 average of $\$ 8.48$ for a $27-\mathrm{kg}$ box at the Fresno shipping point (USDA, 1998). The average June pricing was used because daily fresh celery pricing is not reported until 1 June. To simplify our analysis and to see the effect of yield variability within years and treatments, it was assumed that the fresh celery price was the same in 1998 and 1999. Celery production costs were from data compiled by Imperial County Cooperative Extension (Mayberry et al., 1995) that we adapted to reflect our actual costs for different weed control treatments (e.g., labor for hoeing and herbicide application costs). An additional cost was the change in harvest costs as yield varied for each treatment in each year (Table 3 ).

\section{Results and Discussion}

The 1997-98 experiment will be referred to as 1998 and the 1998-99 growing season as 1999. The ANOVA showed significant $(P \leq 0.05)$ year, weed control treatment, and irrigation practice (drip or sprinkler) effects on celery yield, but no year $\times$ treatment interaction $(P=0.23)$. There was no visible crop injury from any treatment in either 1998 or 1999. All the weed control treatments had equivalent yields that were over five times that of the non-weeded controls. Wild mustard, London rocket, and Italian ryegrass were the dominant weed species in both the sprin-

Table 1. Effect of hand-weeding vs. herbicide applications before (PRE) or after (POST) transplanting of fresh celery plants on weed control ${ }^{\mathrm{z}}$ under drip and sprinkler irrigation systems

\begin{tabular}{|c|c|c|c|c|c|c|c|c|c|}
\hline \multirow[b]{2}{*}{ Treatment } & \multirow[b]{2}{*}{$\mathrm{Kg}$ ai/ha } & \multicolumn{2}{|c|}{ Wild mustard } & \multicolumn{2}{|c|}{ Rye grass } & \multicolumn{2}{|c|}{ Lambsquarters } & \multicolumn{2}{|c|}{ London rocket } \\
\hline & & Sprinkler & Drip & Sprinkler & Drip & Sprinkler & Drip & Sprinkler & Drip \\
\hline \multicolumn{10}{|c|}{1998} \\
\hline Control & N/A & $0.00 \mathrm{e}$ & $0.00 \mathrm{e}$ & $0.00 \mathrm{e}$ & $0.00 \mathrm{e}$ & $0.00 \mathrm{e}$ & $0.00 \mathrm{e}$ & $0.00 \mathrm{e}$ & $0.00 \mathrm{~d}$ \\
\hline Hand-weeding & N/A & $6.33 \mathrm{c}$ & $6.67 \mathrm{c}$ & $6.33 \mathrm{c}$ & $6.67 \mathrm{c}$ & $6.33 \mathrm{~b}$ & $6.67 \mathrm{c}$ & $6.33 \mathrm{c}$ & $6.67 \mathrm{~b}$ \\
\hline Trifluralin E & 0.84 & $2.00 \mathrm{~d}$ & $1.33 \mathrm{~d}$ & $9.00 \mathrm{a}$ & $9.33 \mathrm{a}$ & $2.00 \mathrm{c}$ & $1.33 \mathrm{~d}$ & $2.00 \mathrm{~d}$ & $1.67 \mathrm{c}$ \\
\hline Glyphosate $41 \%$ & 1.12 & $7.33 \mathrm{~b}$ & $7.67 \mathrm{~b}$ & $7.00 \mathrm{~b}$ & $6.33 \mathrm{c}$ & $6.67 \mathrm{~b}$ & $7.67 \mathrm{~b}$ & $7.33 \mathrm{~b}$ & $7.00 \mathrm{~b}$ \\
\hline Prometryn 4L & 1.12 & $10.00 \mathrm{a}$ & $10.00 \mathrm{a}$ & $9.00 \mathrm{a}$ & $8.00 \mathrm{~b}$ & $10.00 \mathrm{a}$ & $10.00 \mathrm{a}$ & $10.00 \mathrm{a}$ & $10.00 \mathrm{a}$ \\
\hline Linuron $50 \%$ & 1.12 & $10.00 \mathrm{a}$ & $10.00 \mathrm{a}$ & $9.00 \mathrm{a}$ & $9.00 \mathrm{a}$ & $10.00 \mathrm{a}$ & $10.00 \mathrm{a}$ & $10.00 \mathrm{a}$ & $10.00 \mathrm{a}$ \\
\hline Sethoxydim & 0.22 & $0.00 \mathrm{e}$ & $0.00 \mathrm{e}$ & $5.00 \mathrm{~d}$ & $5.33 \mathrm{~d}$ & $1.67 \mathrm{e}$ & $0.00 \mathrm{e}$ & $1.67 \mathrm{~d}$ & $0.00 \mathrm{~d}$ \\
\hline $\mathrm{LSD}_{0.05}$ & $\mathrm{~N} / \mathrm{S}$ & 0.35 & 0.24 & 0.49 & 0.55 & 0.55 & 0.24 & 0.38 & 0.38 \\
\hline \multicolumn{10}{|c|}{1999} \\
\hline Control & N/A & $0.00 \mathrm{e}$ & $0.00 \mathrm{~d}$ & $0.00 \mathrm{~d}$ & $0.00 \mathrm{~d}$ & $0.00 \mathrm{~d}$ & $0.00 \mathrm{e}$ & $0.00 \mathrm{e}$ & $0.00 \mathrm{~d}$ \\
\hline Hand-weuding & N/A & $5.63 \mathrm{c}$ & $7.44 \mathrm{~b}$ & $5.13 b$ & $6.38 \mathrm{~b}$ & $4.88 \mathrm{~b}$ & $6.38 \mathrm{~b}$ & $5.88 \mathrm{~b}$ & $5.88 \mathrm{~b}$ \\
\hline Trifluralin E & 0.84 & $6.63 \mathrm{~b}$ & $6.13 \mathrm{~b}$ & $9.88 \mathrm{a}$ & $9.63 \mathrm{a}$ & $5.38 \mathrm{~b}$ & $4.50 \mathrm{c}$ & $5.13 \mathrm{~b}$ & $5.88 \mathrm{~b}$ \\
\hline Glyphosate $41 \%$ & 1.12 & $6.88 \mathrm{~b}$ & $7.25 \mathrm{~b}$ & $5.38 \mathrm{~b}$ & $5.88 \mathrm{~b}$ & $5.75 \mathrm{~b}$ & $6.38 \mathrm{~b}$ & $4.73 \mathrm{c}$ & $6.63 \mathrm{~b}$ \\
\hline Prometryn 4L & 1.12 & $10.00 \mathrm{a}$ & $10.00 \mathrm{a}$ & $9.13 \mathrm{a}$ & $9.25 \mathrm{a}$ & $8.88 \mathrm{a}$ & $8.88 \mathrm{a}$ & $10.00 \mathrm{a}$ & $10.00 \mathrm{a}$ \\
\hline Linuron $50 \%$ & 1.12 & $10.00 \mathrm{a}$ & $10.00 \mathrm{a}$ & $9.44 \mathrm{a}$ & $9.57 \mathrm{a}$ & $8.88 \mathrm{a}$ & $8.88 \mathrm{a}$ & $10.00 \mathrm{a}$ & $10.00 \mathrm{a}$ \\
\hline Sethoxydim & 0.22 & $2.63 \mathrm{~d}$ & $2.00 \mathrm{c}$ & $3.63 \mathrm{c}$ & $2.75 \mathrm{c}$ & $2.38 \mathrm{c}$ & $2.00 \mathrm{~d}$ & $2.38 \mathrm{~d}$ & $1.63 \mathrm{c}$ \\
\hline $\mathrm{LSD}_{0.05}$ & $\mathrm{~N} / \mathrm{S}$ & 1.25 & 1.27 & 1.19 & 1.40 & 1.21 & 1.32 & 0.96 & 0.96 \\
\hline
\end{tabular}

$\overline{{ }^{\mathrm{z}} \text { Weed control evaluations are based on a scale } 0 \text { to } 10 \text {, where } 0=\text { no weed control and } 10=\text { complete weed }}$ control.

Table 2. Mean weeding time (h/ha) and yield (metric tons/ha) of fresh grown celery under drip and sprinkler irrigation.

\begin{tabular}{|c|c|c|c|c|c|}
\hline \multirow[b]{2}{*}{ Treatment } & \multirow[b]{2}{*}{$\mathrm{Kg}$ ai/ha } & \multicolumn{2}{|c|}{$\begin{array}{c}\text { Avg weeding time } \\
\text { (h/ha) after treatment } \\
\end{array}$} & \multicolumn{2}{|c|}{$\begin{array}{c}\text { Yield } \\
\text { (metric tons/ha) }\end{array}$} \\
\hline & & Sprinkler & Drip & Sprinkler & Drip \\
\hline \multicolumn{6}{|c|}{1998} \\
\hline Control & N/A & N/A & N/A & $0.00 \mathrm{~b}$ & $0.00 \mathrm{~b}$ \\
\hline Hand-weeding & N/A & $34.00 \mathrm{ab}$ & $25.00 \mathrm{~b}$ & $2.71 \mathrm{a}$ & $3.78 \mathrm{a}$ \\
\hline Trifluralin & 0.84 & $26.33 \mathrm{bc}$ & $25.67 \mathrm{~b}$ & $2.58 \mathrm{a}$ & $4.19 \mathrm{a}$ \\
\hline Glyphosate & 1.12 & $22.00 \mathrm{c}$ & $22.67 \mathrm{~b}$ & $2.76 \mathrm{a}$ & $4.92 \mathrm{a}$ \\
\hline Prometryn & 1.12 & $4.00 \mathrm{~d}$ & $3.67 \mathrm{c}$ & $2.98 \mathrm{a}$ & $4.19 \mathrm{a}$ \\
\hline Linuron & 1.12 & $4.00 \mathrm{~d}$ & $4.00 \mathrm{c}$ & $2.25 \mathrm{a}$ & $5.24 \mathrm{a}$ \\
\hline Sethoxydim & 0.22 & $38.33 \mathrm{a}$ & $49.00 \mathrm{c}$ & $1.97 \mathrm{a}$ & $2.20 \mathrm{a}$ \\
\hline $\mathrm{LSD}_{0.05}$ & $\mathrm{~N} / \mathrm{S}$ & 7.93 & 4.63 & 6.97 & 8.81 \\
\hline \multicolumn{6}{|c|}{1999} \\
\hline Control & N/A & N/A & N/A & $0.00 \mathrm{~b}$ & $0.00 \mathrm{~b}$ \\
\hline Hand-weeding & N/A & $47.50 \mathrm{a}$ & $42.75 \mathrm{a}$ & $3.54 \mathrm{a}$ & $4.91 \mathrm{a}$ \\
\hline Trifluralin & 0.84 & $27.00 \mathrm{c}$ & $18.75 \mathrm{~b}$ & $3.18 \mathrm{a}$ & $4.45 \mathrm{a}$ \\
\hline Glyphosate & 1.12 & $37.00 \mathrm{~b}$ & $30.00 \mathrm{~b}$ & $3.67 \mathrm{a}$ & $5.02 \mathrm{a}$ \\
\hline Prometryn & 1.12 & $4.00 \mathrm{~d}$ & $4.00 \mathrm{c}$ & $3.63 \mathrm{a}$ & $5.00 \mathrm{a}$ \\
\hline Linuron & 1.12 & $3.25 \mathrm{~d}$ & $3.00 \mathrm{c}$ & $3.16 \mathrm{a}$ & $4.91 \mathrm{a}$ \\
\hline Sethoxydim & 0.22 & $48.00 \mathrm{a}$ & $47.25 \mathrm{a}$ & $2.55 \mathrm{a}$ & $5.31 \mathrm{a}$ \\
\hline $\mathrm{LSD}_{0.05}$ & $\mathrm{~N} / \mathrm{S}$ & 7.97 & 11.41 & 4.28 & 6.17 \\
\hline
\end{tabular}

kler and drip-irrigated fields. Most treatments were slightly less effective in the sprinklerirrigated field. Sprinkler irrigation may increase weed germination and seedling survival by wetting the entire upper soil surface, instead of the narrower, within-row band that is watered in drip irrigation. Prometryn and linuron were the most effective herbicides, providing complete control of most weeds (Table 1). Sethoxydim was the least effective herbicide, providing partial control of only ryegrass (Table 1 ). Trifluralin was the most effective ryegrass herbicide, while glyphosate provided at least partial control of all weed species in both seasons (Table 1).

Combining herbicide applications with hand-hoeing controlled all weed species (Table 2) and eliminated yield loss from weed interference (Table 2). Treatments that were most effective at controlling weeds (Table 2) also had the lowest hand-hoeing costs (Table 3). Linuron and prometryn were the most effective in controlling all weed species in both 1998 and 1999 (Table 2). The additional costs of hand-hoeing these plots were $<\$ 87 /$ ha. The costs of hand-hoeing plots treated with trifluralin, glyphosate, and handweeding were $>\$ 177 /$ ha. Glyphosate and hand-weeding only affected weeds that had emerged at the time of treatment, and therefore required additional hand-hoeing to remove weeds that emerged later in the season (Table 2). Sethoxydim was the least effective herbicide, requiring over 38 hours of labor to hoe all replicates (Table 2), and incurring labor costs over $\$ 1000 /$ ha in both drip and sprinkle irrigated plots (Table 3).

The 1998 and 1999 experimental data were used in partial budget, dominance and marginal analyses to compare costs vs. returns (Fig. 1) and calculate the rates of return from the returns and costs of moving from each treatment to the next higher (more cost, more return) in weed control (Table 5). The highest net return $(\$ 9187 / \mathrm{ha})$ and the lowest additional hoeing (\$87/ha) cost for 1998 was 


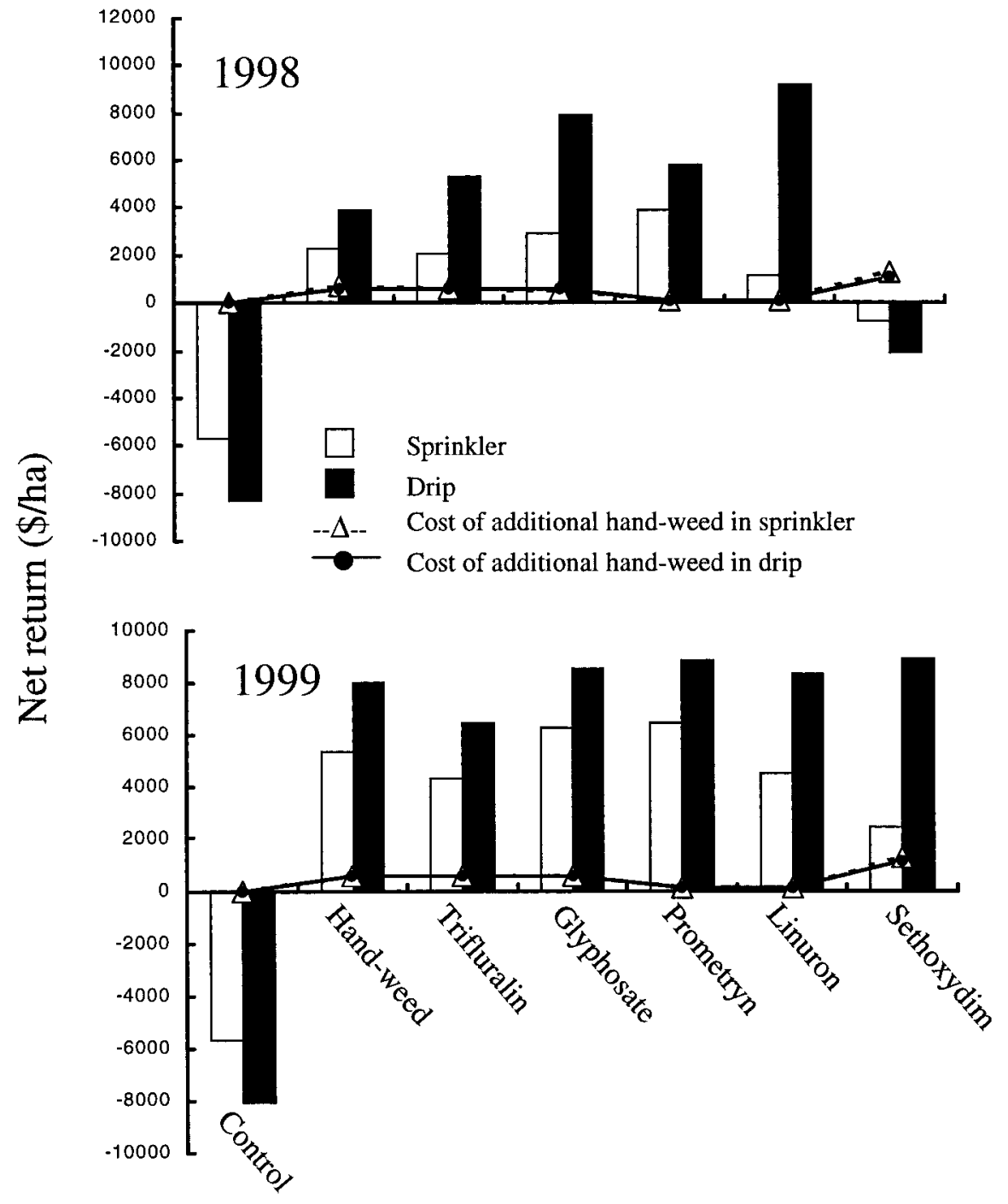

Treatment

Fig. 1. Net return analysis from fresh celery plantings in 1998 and 1999. The height of the bars indicates the potential net profit for each practice. Horizontal lines show the cost of additional hand-weeding in each treatment. Net return was calculated as the difference between the dollar value (revenue) per hectare of each practice minus the total variable cost (growing, hand-weeding, herbicide/applications and harvest cost). linuron in the drip irrigated plot (Fig. 1). This treatment may have increased celery yields by providing better weed control with no crop damage, therefore reducing the additional hoeing cost (Table 3). Drip irrigated plots returned over $\$ 3000 /$ ha for most treatments. Glyphosate and prometryn also produced high net returns (\$7917 and \$5799/ha) in comparison with trifluralin (\$5288/ha) and hand-weeding (\$3904/ha). Both nonweeded and sethoxydim had negative returns ( $\$ 8320$ and $\$ 2084 / \mathrm{ha}$ ). The failure of sethoxydim to control wild mustard (Table 1) resulted in greater labor costs (\$1253/ha) for hand-weeding (Table 3) that resulted in a net loss (Fig. 1).

For the sprinkler irrigated plots, the highest return (\$3921/ha, Fig. 1) and lowest additional hoeing cost (\$87/ha, Table 3) in 1998 was for prometryn. Sprinkler irrigated plots returned over $\$ 1000 /$ ha for most treatments. Glyphosate and hand-weeding had high net returns ( $\$ 2887$ and \$2298/ha) in comparison with trifluralin (\$2028/ha) and linuron (\$1148/ ha). The nonweeded control and sethoxydim had negative returns ( $\$ 5948$ and $\$ 734 / \mathrm{ha}$ ), mostly because of high weed populations in the untreated control plots and greater labor costs $(\$ 1253 /$ ha) when sethoxydim was used (Table 3).

Marginal analysis (Table 5) ranked the weed control treatments in the 1998 drip irrigated plots by comparing the next higher costs and returns of nondominated treatments from Table 4. A treatment is nondominated when it produces higher returns than an alternative treatment with lower costs (Bell et al., 2000). Or for each of these treatments, there is another alternative with a higher net return and lower variable cost. Trifluralin, sethoxydim, and the nonweeded control were removed from the marginal analysis because of lower benefits and higher costs. Prometryn and linuron returned $\$ 1.44$ and $\$ 1.03 /$ ha for every dollar of investment compared with (\$0.59/ha) for glyphosate. In drip irrigated celery in 1998, prometryn produced the highest marginal rate $(144 \%)$ of return on investment. For 1998 sprinkler irrigated celery, glyphosate had the highest return of (\$1.56/

Table 3. Variable costs as influenced by weed control practices for fresh celery production under drip and sprinkler irrigation (\$/ha).

\begin{tabular}{|c|c|c|c|c|c|c|c|c|c|c|c|c|c|c|}
\hline \multirow[b]{2}{*}{ Operation } & \multicolumn{2}{|c|}{ Untreated } & \multicolumn{2}{|c|}{ Hand-weeding } & \multicolumn{2}{|c|}{ Trifluralin } & \multicolumn{2}{|c|}{ Glyphosate } & \multicolumn{2}{|c|}{ Prometryn } & \multicolumn{2}{|c|}{ Linuron } & \multicolumn{2}{|c|}{ Sethoxydim } \\
\hline & Sprinkler & Drip & Sprinkler & Drip & Sprinkler & Drip & Sprinkler & Drip & Sprinkler & Drip & Sprinkler & Drip & Sprinkler & Drip \\
\hline \multicolumn{15}{|c|}{1998} \\
\hline Growing $^{z}$ & 5984 & 8320 & 6122 & 8402 & 6099 & 8404 & 6068 & 8404 & 6032 & 8332 & 6066 & 8333 & 6185 & 8484 \\
\hline Hand-weeding ${ }^{y}$ & 0 & 0 & 743 & 547 & 576 & 561 & 481 & 561 & 87 & 80 & 87 & 87 & 1253 & 1096 \\
\hline Herbicides/ & & & & & & & & & & & & & & \\
\hline application $^{\mathrm{x}}$ & 0 & 0 & 178 & 178 & 190 & 190 & 78 & 78 & 232 & 232 & 455 & 455 & 87 & 87 \\
\hline Harvest $^{\mathrm{w}}$ & 0 & 0 & 13112 & 18315 & 12463 & 20265 & 13438 & 23841 & 14413 & 20265 & 10945 & 25359 & 9537 & 10620 \\
\hline \multicolumn{15}{|c|}{1999} \\
\hline Growing & 5710 & 8046 & 5893 & 8186 & 5872 & 8107 & 5843 & 8144 & 5758 & 8059 & 5789 & 8056 & 5881 & 8201 \\
\hline Hand-weeding & 0 & 0 & 743 & 547 & 576 & 561 & 481 & 561 & 87 & 80 & 87 & 87 & 1253 & 1096 \\
\hline Herbicides/ & & & & & & & & & & & & & & \\
\hline application & 0 & 0 & 178 & 178 & 190 & 190 & 78 & 78 & 232 & 237 & 455 & 455 & 87 & 87 \\
\hline Harvest & 0 & 0 & 17123 & 23733 & 15389 & 21566 & 17773 & 24275 & 17556 & 24167 & 15280 & 23733 & 12354 & 25684 \\
\hline
\end{tabular}

${ }^{2}$ Exclusive of weed control (from Mayberry et al., 1994).

y Hand-weeding costs after treatment $(\$ / \mathrm{ha})$.

${ }^{x}$ Herbicide/application (\$/ha).

${ }^{w}$ Based upon $\$ 4.75 / \mathrm{h}$. 
Table 4. Dominance analysis for dominated and nondominated treatments for fresh grown celery weed control in 1998 and 1999 (\$/ha). ${ }^{\mathrm{z}}$

\begin{tabular}{|c|c|c|c|}
\hline Rank & Treatment & $\begin{array}{l}\text { Net } \\
\text { return }\end{array}$ & $\begin{array}{c}\text { Total } \\
\text { variable } \\
\text { cost }\end{array}$ \\
\hline
\end{tabular}

\section{Sprinkler} irrigation

\begin{tabular}{|c|c|c|c|}
\hline 1 & Prometryn & 3920.80 & $19,430.48$ \\
\hline 2 & Glyphosate & 2887.30 & $18,740.06$ \\
\hline 3 & Hand-weed & 2297.91 & $18,937 \cdot 65^{y}$ \\
\hline 4 & Trifluralin & 2028.32 & $18,188.56$ \\
\hline 5 & Linuron & 1147.50 & $16,483.50$ \\
\hline 6 & Sethoxydin & -734.25 & $16,171.17^{y}$ \\
\hline 7 & Control & -5984.27 & 5984.27 \\
\hline \multicolumn{4}{|c|}{$\begin{array}{l}\text { Drip } \\
\quad \text { irrigation }\end{array}$} \\
\hline 1 & Linuron & 9186.82 & $31,873.82$ \\
\hline 2 & Glyphosate & 7916.62 & $30,636.50$ \\
\hline 3 & Prometryn & 5799.10 & $27,033.74$ \\
\hline 4 & Trifluralin & 5287.57 & $27,545 \cdot 27^{y}$ \\
\hline 5 & Hand-weed & 3903.64 & $25,716.44$ \\
\hline 6 & Sethoxydin & -2083.59 & $19,322.79^{y}$ \\
\hline 7 & Control & -8319.75 & $8319.75^{y}$ \\
\hline
\end{tabular}

Sprinkler irrigation

\begin{tabular}{lcrc}
1 & Prometryn & 6435.42 & $22,009.26$ \\
2 & Glyphosate & 6248.96 & $22,509.16^{\mathrm{y}}$ \\
3 & Hand-weed & 5388.73 & $22,350.71^{\mathrm{y}}$ \\
4 & Linurous & 4560.79 & $20,200.97$ \\
5 & Trifluralin & 4324.13 & $20,594.35^{\mathrm{y}}$ \\
6 & Sethoxydin & 2465.82 & $19,553.34$ \\
7 & Control & -5710.20 & $5710.20^{\mathrm{y}}$ \\
rip & & & \\
irrigation & & & \\
1 & Sethoxydin & 8920.09 & $32,689.07$ \\
2 & Prometryn & 8864.19 & $30,315.81$ \\
3 & Glyphosate & 8521.20 & $30,815.52^{\mathrm{y}}$ \\
4 & Linuron & 8326.65 & $30,148.11$ \\
5 & Hand-weed & 8014.62 & $30,460.14^{\mathrm{y}}$ \\
6 & Trifluralin & 6480.56 & $28,389.64$ \\
7 & Control & -8045.68 & $8045.68^{\mathrm{y}}$ \\
\hline
\end{tabular}

${ }^{\mathrm{z}} \mathrm{A}$ dominance analysis was carried out by first listing the treatments in order of increasing variable costs and returns. Any treatment that has net returns that are less than or equal to those of a treatment with lower variable cost is dominated otherwise the treatment is considered nondominated.

${ }^{y}$ Dominated treatments, therefore they were eliminated from further analysis.

ha) for every dollar invested when compared with prometryn $(\$ 1.50 / \mathrm{ha})$. The rate of returns from trifluralin were $<52 \%$, the same year, so sethoxydim and hand-weeding were dropped from further analysis.

Regardless of irrigation systems, higher yields were recorded in 1999 (Table 2), which resulted in higher returns (Fig. 1). Sethoxydim, prometryn, glyphosate and linuron returned over $\$ 8,500 /$ ha under drip-irrigation. The returns on the hand-weeding and trifluralin were also high (Fig. 1), and there was a net loss of $\$ 8046 /$ ha when no weed control was used. Prometryn (\$80/ha) and linuron (\$87/ ha) had the lowest additional hand-hoeing costs. The additional hoeing costs for handweeding, trifluralin, or glyphosate treatments in 1999 drip-irrigated celery was $>\$ 500 /$ ha . Sethoxydim had the highest hoeing cost (\$1096/ha) in 1999. Sethoxydim yield was

Table 5. Marginal rate of return from hand-weed and herbicide treatments for fresh celery in 1998 and 1999. The marginal rates are based on partial budget and marginal analysis of nondominated treatments. All calculated values are in $\$ /$ ha.

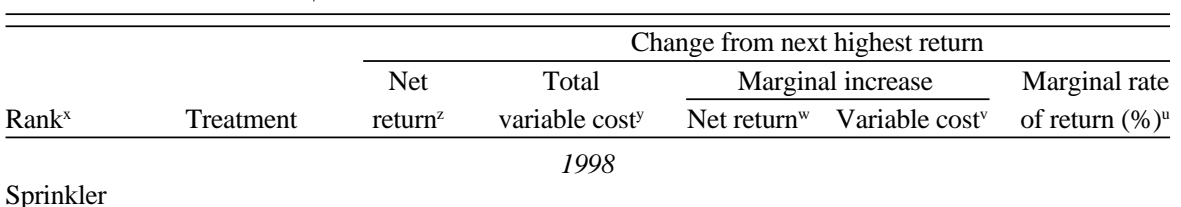

Sprinkler

irrigation

$\begin{array}{lcrrrrr}1 & \text { Prometryn } & 3920.80 & 19430.48 & 1033.50 & 690.42 & 149.69 \\ 2 & \text { Glyphosate } & 2887.30 & 18740.06 & 858.98 & 551.50 & 155.75 \\ 4 & \text { Trifluralin } & 2028.32 & 18188.56 & 880.82 & 1705.06 & 51.66 \\ 5 & \text { Linuron } & 1147.50 & 16483.50 & & & \end{array}$

Drip irrigation

1
2
3
5

$\begin{array}{crrrrr}\text { Linuron } & 9186.82 & 31873.82 & 1270.20 & 1237.32 & 102.66 \\ \text { Glyphosate } & 7916.62 & 30636.50 & 2117.52 & 3602.76 & 58.77 \\ \text { Prometryn } & 5799.10 & 27033.74 & 1895.46 & 1317.30 & 143.89\end{array}$

Sprinkler

irrigation

1

4

6

Drip

irrigation

1
2
4

Hand-weed $\quad 3903.64 \quad 25716.44$

1999

$\begin{array}{crrrrr}\text { Prometryn } & 6435.42 & 22009.26 & 1874.63 & 1808.29 & 103.67 \\ \text { Linuron } & 4560.79 & 20200.97 & 2094.97 & 647.63 & 323.48 \\ \text { Sethoxydim } & 2565.82 & 19553.34 & & & \end{array}$

Net return was calculated as mean yield (Table 2 ) $\times \$ /$ ha @7836 minus total variable cost.

yTotal variable cost included growing, hand-weeding, herbicide/application, and harvest cost.

${ }^{x}$ Net return and cost were ranked from highest to lowest.

${ }^{\text {w} M a r g i n a l ~ r e t u r n ~ o f ~ e a c h ~ t r e a t m e n t ~ w a s ~ c a l c u l a t e d ~ b y ~ s u b t r a c t i n g ~ f r o m ~ i t s ~ o w n ~ n e t ~ r e t u r n ~ t h e ~ n e t ~ r e t u r n ~}$ of the next lower raking treatment.

${ }^{v}$ Marginal costs were calculated in the same manner as the marginal net return.

"Marginal rate of return was the result of dividing the marginal net return by its corresponding marginal cost (multiplied by 100 to express a percentage). For example, in 1998 drip irrigated plots using treatment 5 hand-weed as a base, the marginal net return for treatment 3 prometryn was $\$ 5799.10-\$ 3903.64=$ $\$ 1895.46$. Its marginal variable cost was calculated in the same manner. Marginal rate of return for the same treatment 3 was $(\$ 1895.26 / \$ 1317.30) * 100=144 \%$. In other words, the $\$ 1317.30$ was invested for prometryn, returned $\$ 1317.30+\$ 1895.46=\$ 3212.76$ more. But using treatment 6 sethoxydim in 1999 sprinkler irrigated celery as a base, the marginal rate of return for adopting linuron treatment 4 was the highest: $323.38 \%$.

The lowest ranking treatment has zero marginal returns and costs.

also higher (5.31 metric tons/ha) in 1999; therefore, the associated net return (\$8920) was the highest.

Yield in the sprinkler irrigated field was higher in 1999 than in 1998. Prometryn produced the highest return $(\$ 6435 / \mathrm{ha})$ with the lowest labor cost for hand-hoeing ( $\$ 87 / \mathrm{ha}$ ) under sprinkler irrigation. Glyphosate and hand-weeding also produced higher net returns in 1999 of $\$ 6249 /$ ha for glyphosate and $\$ 5389 /$ ha for hand-weeding than for either trifluralin (\$4324/ha) or sethoxydim (\$2466/ ha). The nonweeded control had a net loss of $\$ 5710 /$ ha. The additional weeding cost (\$1253/ha) for sethoxydim was higher in comparison with glyphosate, hand-weeding, and trifluralin (Table 3 ). The lower yield of 2.55 metric tons/ha and higher labor weeding cost may have contributed to a decreased net return from sethoxydim in 1999.

In 1999 drip irrigated celery, the marginal analysis ranked prometryn as the most favorable treatment in terms of incremental return and costs with a $321 \%$ rate of return. The next highest ranked treatment was linuron, which returned $105 \%$ of each dollar invested. The marginal rate of returns in 1999 sprinkler irrigated celery found prometryn, linuron, and sethoxydim as nondominated treatments. Linuron had the highest rate of return (324\%), followed by prometryn, with a $104 \%$ rate of return.

Overall, the weight of celery harvested in 1999 was much higher than the previous year. Despite high costs of installation and management of a drip irrigation system, dripirrigated celery resulted in significantly higher marketable celery yield than sprinkler irrigation in 1998 and 1999 trials. The net returns for drip were much higher than for sprinkler irrigation. In terms of selecting the best alternative treatment in drip or sprinkler irrigated celery in 1998 or 1999, marginal analysis favored prometryn and linuron with over $100 \%$ rate of return on each dollar invested. Prometryn and linuron are the most commonly used herbicides in celery production worldwide (William et al., 2000). They effectively control most of the young emerged annual weeds common to celery production (Table 1). Prometryn and linuron also had the lowest additional costs for hand-hoeing of all 
the weed control practices tested. Reduced labor costs for hand-hoeing made prometryn and linuron the most valuable treatments for weed control in both drip and sprinkler irrigation celery (Fig. 1). This result indicated that prometryn and linuron are efficient and costeffective herbicides for weed control in both drip and sprinkler irrigated celery, however, drip irrigation was favored over sprinkler irrigation.

\section{Literature Cited}

Bell, C.E., B.E. Boutwell, E.J. Ogbuchiekwe, and M.E. McGiffen. 2000. Weed control in carrot (Daucus carota L.): The efficacy and economic value of linuron weed sciences. HortScience 35(6): 1089-1091.

Centro Internacional de Mejoramiento de Maiz y Trigo. 1988. From agronomic data to farmer recommendations: An economic training manual. Completely rev. ed. Mexico, D.F.
California Dept. of Food and Agriculture: Production Statistics 1996. Online at http://www.cdfa. ca.gov/kids/commodities/celery.html

Erik, B.G., C.S. Clinton, and L. Saunders. 1995. A comparison of onion production under sprinkler, subsurface drip, and furrow irrigation. HortScience 30(4):839. (Abstr.).

Hartz, T. 2000. Drip irrigation and fertigation management of celery. Vegetable Research and Information Center, Vegetable Production Series. Univ. of Calif., Div. of Agr. and Natural Resources. Coop. Ext. Publ. 7220.

Koike, S.T., Schulbach, K.F., and E. William. 1996. Celery production in California. Vegetable Research and Information Center, Vegetable Production Series. Univ. of Calif., Div. of Agr. and Natural Resources. Coop. Ext. Publ. 7220.

Little, E.L, S.T. Koike, and R.L. Gilbertson. 1997. Bacterial leaf spot of celery in California: Etiology, epidemiology, and role of contaminated seed. Plant Dis. 81(8):892-896.

Mayberry, K.M., R.A. Natwick, A. Gonzalez, G.H.
Holmes, C.E. Bell, and K.M. Bali. 1995. Guidelines to production costs and practices. Circular 104-V. Univ. of Calif. Coop. Ext., Imperial Co.

Perrin, R.K, D.L. Winkelmann, E.L. Moscardi, and J.R. Anderson. 1976. From agronomic to farmer recommendations: An economics training manual. International Maize and Wheat Improvement Ctr., Trigo, Mexico City.

U.S. Dept. of Agriculture (USDA)/National Agricultural Statistics Service. (2000) 1999. Statistics of vegetables and melons. http:// www.usda.gov/nass/pubs/agr00/00_ch4.pdf

U.S. Dept. of Agriculture (USDA) Marketing Service. 1997. Online at http://www.ams.usda.gov/ mncs/mnreport/WA_FV120.txt

U.S. Environmental Protection Agency. Online at http//www.cdpr.ca.gov/docs/monster/ monster2.htm

William, M., J.A. Dusky. 1999. March 1999 Weed control in celery. Hort.Sci. Dept., Florida. Coop. Ext. Serv., Inst. of Food and Agr. Sci., Univ. of Fla. Fact Sheet HS-202. http://edis.ifas.ufl.edu/ WG027. 